\title{
Strategies and Financial Instruments for Facing Main Risks in Cruise Industry
}

\author{
Rosa Caiazza \\ Parthenope University of Naples, Italy
}

\begin{abstract}
The cruise industry has enjoyed dynamic growth over a period of 30 years. Factors that have affected the market's growth are socio economic changes in the lifestyle of people, reduction of prices and vertical and horizontal integration of tour operators. Competition is dominated by the three cruise groups: the Carnival Corporation, Royal Caribbean International, and Star Cruises. Competition inside the cruise industry, between the main groups, and outside the industry, in the form of land-based resorts and hotels, can affect company business. In the competitive international cruise industry, there are a number of factors that affect companies' performances: the general economic and business conditions, reduction in consumer demand for cruises, and changes in operating and financing costs. Cruise groups try to minimize these risks through a combination of the normal operating and financing activities and through the use of financial instruments. The aim of this article is to identify the strategies and the financial instruments used to face main risks and compete globally in cruise industry.
\end{abstract}

Keywords: cruise industry, international strategies, global competiveness, risk analysis

\section{Introduction}

Cruise industry is dominated by Carnival Corporation, Royal Caribbean International, and Star Cruises. Competition inside the cruise industry, between the main groups, and outside the industry, in the form of land-based resorts and hotels, can affect company business. In the competitive international cruise industry, there are a number of factors that affect companies' performances. Reduction in consumer demand for cruises can result from any number of reasons, including geo-political and economic uncertainties and the unavailability of air service, the international political and economic climate, armed conflicts, terrorist attacks and threats thereof, availability of air service and other world events. Negative incidents, unusual weather conditions or natural disasters, such as hurricanes and earthquakes and the impact of which can cause the alteration of itineraries or cancellation of a cruise or series of cruises. Finally changes in operating and financing costs, including changes in foreign currency, interest rates, fuel, food, payroll, insurance, and security costs can impact on business performances. In the next sections of the article, the author tries to identify main characteristics of the cruise industry, the sources of risks, and the financial instruments used to face them.

Rosa Caiazza, Ph.D., Assistant Professor, Department of Business, Parthenope University of Naples, Visiting Researcher at Wharton University of Pennsylvania and Univeristè Libre de Bruxelles.

Correspondence concerning this article should be addressed to Rosa Caiazza, via Medina 40, 80133, Napoli (IT). E-mail: rosa.caiazza@uniparthenope.it. 


\section{Strategies for Competing Globally}

The modern day cruise concept was born in 1950s when the introduction of jet airliner forced large transatlantic liner companies to seek alternate usage for their ships (Cartwright \& Baird, 1999; Ward, 2005; Santangelo, 1984; Frankel, 1987). When cruise industry was still focused on the destination of Carnival group introduced the fun-ship experience. The promise of fun would direct the company's marketing strategy for the next years. The new ships reflected the fun concept with bright colours and neon lighting casinos, live music and discos that changed the image of cruising and attracted new target of people. To communicate the brand message, Carnival crafted marketing communications that articulated the fun ships image by showing the ships and their entertainment architecture, as well as by featuring guests dining, dancing, playing, swimming, sunning, and socializing at an affordable price.

Thus cruise industry becomes a solid participant on the leisure and hospitality industries. As competition within the cruise industry grew, started designing larger ships to maximize the benefits of economies of scale and reduced prices in order to attract a broader mix of passengers (Mancini, 2003). Lesser operational expenses and an increase in cruise and on-board revenues fuelled the drive for bigger, more efficient and more appealing ships (Garin, 2005). One-third of the market sailed the premium cruise lines but cruising was dominated by brands that served as the contemporary segment, a clever label used by cruise marketers to describe the mass market. Competition for the contemporary customer was fierce both inside the industry, among Carnival, Royal Caribbean, and Princess Cruises, and outside the cruise industry in the form of land-based resorts and hotels in sightseeing destinations.

Carnival, Royal Caribbean, and Princess Cruises have all seen an increase in their profit margins brought upon by the introduction of modern 3,000 passenger vessels in the Caribbean and Europe. As an example, Moody's Investor Service recently upgraded the long-term debt rating of the industry's second largest operator, Royal Caribbean Cruises, based upon the steady growth in earnings and cash flow from its expanding fleet of cruise ships. According to Moody's, the rating is stable reflecting the favourably industry conditions. The competitive structure in the cruise industry changed around the turn of the 21st century. Price wars and soft demand decimated the budget sector, with brands such as Regal, Premier, and Commodore unable to compete with the bigger brands' new ships and attractive prices. The cost reduction has started an increase process that has not been arrested to the day's nostril (Klein, 2002; Garin, 2005).

The cruise industry has enjoyed dynamic growth over a period of 25 years, driven mainly by demand from North America that is the main source market, covering two-third of the market, followed by Europe which cover one-fourth of the global market (Dickinson \& Vladimir, 2007). Fueled by the benefits derived from a demand driven by supply scenario, the cruise industry has steadily become a major player in the leisure, hospitality, and vacation markets. Over a similar period, global, mainly land-based tourism has grown by less than $50 \%$. Better product positioning, changing demographics, a healthy economy, a wider range of cruise lengths and departure points, and the addition of innovative amenities and onboard facilities, have all played a role in the industry's rapid growth.

Factors affected cruise market's growth can be lead back to the socio economic changes in the lifestyle of people that more and more people are able to follow the fashion trend of cruise vacation; technology development and increased size of the ships reduced the prices of this kind of product that become more accessible for the middle-class clientele; higher number of cruise operators, services and facilities, vertical and horizontal integration of tour operators also contributed to the fast grow of this sector (Stopford, 1997). 
Product differentiation within the cruise product is to appeal to different target audiences such as the children with the increasing development of child friendly offerings. Demographics suggest that with the stagnated birth rate in Europe and the ageing of the baby boom generation, the grey market will become increasingly important in the years ahead. Paradoxically a number of European cruise markets, notably Germany and Spain, have had success in attracting younger people to cruising. A considerable latent demand for cruising is present in Europe in particular among those who aspire to take a cruise but have not yet done. Specifically, growth in demand is expected among new European Union citizens in Eastern Europe, as their lifestyles become more closely aligned with the more affluent older member-countries with greater disposable income resources (Dowling, 2006).

As it is possible to see from Wild International data, the first geographic area in cruising sector as number of passengers and also as area of destination is America, followed from Europe in which the top five source markets are UK, Germany, Italy, Spain, and France, accounted for $86 \%$ of the total market.

Competition is dominated by the main cruise groups, the Carnival Corporation, Royal Caribbean International, and Star Cruises enjoy a combined market share of over $85 \%$. The remainder of the industry is shared amongst smaller operators such as Disney Cruise Lines and the ultra-luxury operators such as Crystal Cruises, Silverseas Cruises, and Radisson Seven Seas Cruises.

The Carnival Corporation, Royal Caribbean, and Star Cruises are by far the most visible in the industry and their moves tend to determine industry direction and the nature of the competition. The larger lines tend to have a much broader line of service and market segmentation, while the smaller lines tend to be more specialized by serving niche markets and special itineraries catering to specific market segments. Historically this industry has been highly lucrative with high profit margins, below average competition, steadily rising sales, and solid financial performances (Klein, 2002).

The big economic subjects control a lot of juridical subjects that operate through different brands in more than one geographic area and segment of the global cruising market. In this way they combine advantage of big dimension with the differentiation of products. They base their success on market share, financial position, product quality, consumer loyalty, sales distribution, global expansion, organization structure, production capacity, advertising, customer service, and management experience. They expand continuously their fleet increasing amount of destinations, itineraries, and markets and move their fleets throughout the year to meet the seasonal demand.

Among the 100 brands actually active in the global cruise market, 44 are domiciled in Europe, 35 are American and the other ones are domiciled in the other parts of the world. In particular some brands have only one vessel and the other more than 10 such as Carnival Cruise Line with 21 ships, Royal Caribbean International with 19 ships, Princess Cruises with 14 ships, Holland American Line with 12 ships, and Costa with 11 ships.

Each brand competes with the others offering a fleet of ships that belong to different segments. First factor of differentiation is the size of their ships. Generally the most expansive cruises are organized on ships with lower members of berths. Most expansive cruises also have a longer and more sophisticated itinerary and more attractive activities on the boat and on the land. On the contrary, commercial cruises have a shorter itinerary and they are cheaper (Mancini, 2003).

\section{Financial Instruments for Facing Main Risks}

Using data and information from the official reports of Carnival Corporation, Royal Caribbean 
International, and Star Cruises in this part of the article the author tried to summarize main risks in cruise industry and financial instrument used to face them.

Cruise revenues come from tickets, the sale of air and other transportation to and from the ships and the sale of goods and services primarily onboard, such as bar, casino gaming, shore excursions, gift shop and spa sales, photo and art sales, and pre and post-cruise land packages. These goods and services are either provided directly by the company or by independent concessionaires, from which company receives a percentage of a fee (Drewry Shipping Consultants, 1998a).

Cruise expenses are the costs of passenger cruise tickets, which represent costs that vary directly with passenger cruise ticket revenues, and include travel agent commissions, air and other travel related costs, onboard and other cruise costs. Concession revenues do not have any significant amount of costs associated with them, as the costs and services incurred for these activities are provided by concessionaires, payroll, and related costs, which represent costs for all shipboard personnel, including deck and engine officers and crew and hotel and administrative employees, fuel costs, which include fuel delivery costs, food costs, which include both our passenger and crew food costs, and other ship operating costs, which include repairs and maintenance, including minor replacements and dry-dock expenses, port charges, insurance, entertainment and all other shipboard operating costs and expenses (Drewry Shipping Consultants, 2001b).

In the competitive international cruise industry, there are a number of factors that affect companies' performances. The general economic and business conditions can adversely impact the levels of potential vacationers' discretionary income and thereby reduce the net revenue yields for cruise brands (Drewry Shipping Consultants, 1998b). Competition among different cruise ship operators and providers of other vacation alternatives, tax laws, and regulations can affect company business. Reduction in consumer demand for cruises can result from any number of reasons, including geo-political and economic uncertainties and the unavailability of air service, the international political and economic climate, armed conflicts, terrorist attacks and threats thereof, availability of air service and other world events. Negative incidents, unusual weather conditions or natural disasters, such as hurricanes and earthquakes and the impact of that can cause the alteration of itineraries or cancellation of a cruise or series of cruises. Finally changes in operating and financing costs, including changes in foreign currency, interest rates, fuel, food, payroll, insurance and security costs can impact on business performances (Drewly Shipping Consultants, 2001a).

The functional currency used by cruise companies is the US dollar. Transactions in foreign currencies are translated into US dollars at the exchange rate in effect at the transaction dates. Monetary assets and liabilities expressed in foreign currencies are translated at exchange rates at the balance sheet date. Cruise companies for their global nature are exposed to market risks tie to the changes in operating and financing costs, including changes in foreign currency, interest rates, and fuel.

They try to minimize these market risks through a combination of the normal operating, financing activities, and derivative financial instruments (Kavussanos, Visvikis, \& Batchelor, 2004). The financial impacts of these hedging instruments are primarily offset by corresponding changes in the underlying exposures being hedged. Companies achieve this by closely matching the amount, term and conditions of the derivative instrument with the underlying risk being hedged (Stokes, 1997). Their exposure under foreign currency contracts, interest rate and fuel swap agreements is limited to the cost of replacing the contracts in the event of non-performance by the counterparties to the contracts, all of which are their lending banks.

Using data end information from the official documents, it is possible to evidence that Royal Caribbean 
International primary exposure to foreign currency exchange rate risk relates to firm commitments under ship construction contracts denominated in Euros. Company enters into euro-denominated forward contracts to manage this risk. Approximately $11 \%$ of the aggregate cost of the ships was exposed to fluctuations in the euro exchange rate. Company is also exposed to foreign currency exchange rate fluctuations on the United States dollar value of foreign currency denominated forecasted transactions. To manage this exposure, RCI takes advantage of natural offsets of its foreign currency revenues and expenses and enters into foreign currency forward contracts for a portion of the remaining exposure related to these forecasted transactions. Company's principal net foreign currency exposure relates to the Euro, the British pound, and the Canadian dollar. Royal Caribbean has foreign currency forward contracts in a notional amount of \$3.8 billion maturing through 2010 . The fair value of foreign currency forward contracts related to the six ship construction contracts designated as fair value hedges is a net unrealized gain of approximately \$106.3 million. Also, company considers its investments in foreign subsidiaries to be denominated in relatively stable currencies and of a long-term nature. It partially addresses the exposure of its investments in foreign subsidiaries by denominating a portion of its debt in subsidiaries' functional currencies.

Using data end information from the official documents, it is possible to evidence that Carnival has foreign currency swaps designated as foreign currency fair value hedges for two of our Euro-denominated shipbuilding contracts whose fair value was an unrealized loss of \$26 million. However company has six Euro-denominated shipbuilding commitments aggregating Euro 2.55 billion for which it does not enter into any foreign currency swaps. Carnival considers its investments in foreign subsidiaries to be denominated in relatively stable currencies and of a long-term nature. In addition to the strategy discussed above, company also partially addresses these exposures by denominating a portion of its debt, or entering into foreign currency swaps, in its subsidiaries' functional currencies. Specifically, Carnival has debt of 1.02 billion in Euros and 419 million in sterling and have 1.25 billion of foreign currency swaps, whereby company has converted \$267 million of U.S. dollar debt into sterling debt, \$842 million of U.S. dollar debt into Euro debt and \$143 million of Euro debt into sterling debt, thus partially offsetting this foreign currency exchange rate risk. The fair value of these foreign currency swaps is an unrealized loss of $\$ 169$ million.

Using data end information from the official documents, it is possible to evidence that Star Cruises exposure to foreign currency exchange rate risk relates primarily to the ship building contracts and the Euro-denominates debt. The ship contracts are denominated into Euro and the associated debt agreements are denominated in either the US dollar or Euro with certain conversion options. From time to time, company enters into foreign currency forward contracts and option contracts for this payment. Star Cruises has approximately Euro 598 million of the total outstanding loan denominated in Euros. Star Cruise's principal net foreign currency exposure relates to the Singapore dollar, the Hong Kong dollar, and the Euro. To manage this exposure, the Star Cruise takes advantage of any natural offset of the group's foreign currency revenues and expenses and from time to tie enters into foreign currency forward contracts and option contracts for a portion of the remaining exposure related to these forecasted transactions. Star Cruises is a party to certain forward contracts with a total outstanding notional amount of US\$49.1 million in respect of the Singapore dollars.

Royal Caribbean International's exposures to market risk for changes in interest rates relate to long-term debt obligations and operating lease for Brilliance of the Seas. Sixty percent of company's long-term debt is effectively fixed and $40 \%$ is floating. Royal Caribbean enters into interest rate swap agreements to modify its 
exposure to interest rate movements and to manage its interest expense and rent expense. Market risk associated with long-term fixed rate debt is the potential increase in fair value resulting from a decrease in interest rates. Company's interest rate swap agreements effectively change $\$ 175.0$ million of fixed rate debt with a weighted average fixed rate of $8.11 \%$ to Libor-based floating rate debt. Company has an interest rate swap agreement that effectively changes $\$ 25.0$ million of Libor-based floating rate debt to fixed rate debt of $4.40 \%$.

Carnival seeks to minimize the impact of fluctuations in interest rates through long-term investment and debt portfolio strategies, which include entering into a substantial amount of fixed rate debt instruments. Company continuously evaluates its debt portfolio, and makes periodic adjustments to the mix of floating rate and fixed rate debt based on its view of interest rate movements through the use of interest rate swaps. Seventy two percent of the interest cost on long-term debt is effectively fixed and $28 \%$ is variable, including the effect of company's interest rate swaps. Specifically, company has interest rate swaps which effectively changed \$932 million of fixed rate debt to Libor-based floating rate debt. In addition, it has interest rate swaps which effectively changed $\$ 365$ million of Libor-based floating rate debt to fixed rate debt.

The majority of the Star Cruises' indebtedness and its related interest expenses are denominated in US dollars and are based upon floating rates of interest. In order to limit its exposure to interest rates fluctuation, variable to fixed interest rate swaps has been utilized from time to time, to fix a portion of interest costs over a period of time. Star Cruises continuously evaluates its debt portfolio, including interest rate swaps to achieve a desired proportion of variable and fixed rate debt based on its view of interest rate movement. Star Cruises has interest rate swap on debts with a total outstanding notional amount of \$263.3 million with remaining from one to five years. In addition, Star cruises has a series of 5.5\% capped USD Libor in-arrears interest rate swaps with a total outstanding notional amount of approximately US\$66.2 million to limit its exposure to fluctuations movements if the London Interbank Offer Rate (LIBOR) rate moves beyond the cap level of 5.5\% with the remaining lives of two years. With these interest rate swaps in place and the conversion of certain portion of the borrowing from Libor-Based rate to a fixed rate at $41 \%$ of the company's debts are fixed and remaining $59 \%$ are floating. Royal Caribbean's fuel cost (net of the financial impact of fuel swap agreements) as a percentage of its total revenues, is approximately 9.2\%. Historically, company has used fuel swap agreements to mitigate the financial impact of fluctuations in fuel prices. Company has fuel swap agreements to pay fixed prices for fuel with an aggregate notional amount of approximately \$205.3 million. Carnival has typically not used financial instruments to hedge its exposure to the bunker fuel price market risk. Star Cruises' fuel costs, as a percentage of the total revenues, is approximately $8.6 \%$. Company uses fuel hedging agreements to mitigate the financial impact of fluctuations in fuel prices. Company has fuel swap agreements to pay fixed prices for fuel with an aggregate outstanding notional amount of approximately US\$18.9 million.

\section{Conclusions and Discussion}

In the article the author discussed cruise industry structure and its evolution over time. The author evidenced as main factors that affect companies' performances the general economic and business conditions, reduction in consumer demand for cruises, and changes in operating and financing costs. Then the author discussed how cruise groups try to minimize these risks through a combination of the normal operating, financing activities, and financial instruments. 


\section{References}

Cartwright, R., \& Baird, C. (1999). The development and growth of the cruise industry. Oxford, UK: Butterworth-Heinemann. Cruise Lines International Association (CLIA), Spring 2005, Industry Overview.

Dickinson, B., \& Vladimir, A. (2007). Selling the sea: An inside look at the cruise industry. New York: John Wiley.

Dowling, R. K. (2006). Cruise ship tourism. CABI Publishing.

Drewry Shipping Consultants. (1998a). Ship finance. London, England.

Drewry Shipping Consultants. (1998b). World ship building. London, England.

Drewly Shipping Consultants. (2001a). Briefing report, Ltd. shipping future and derivatives: From biffex to forward freight agreements (FFAs) and beyond. London, England.

Drewry Shipping Consultants. (2001b). Ship finance \& investment. London, England.

Frankel, E. G. (1987). The world shipping industry. London and New York: Croom Helm.

Garin, K. (2005). Devils on the deep blue sea. New York: Viking.

Kavussanos, M. G., Visvikis, I. D., \& Batchelor, R. A. (2004). Over-the-counter forward contracts and spot price volatility in shipping. Transportation Research, 40(3), 273-296.

Klein, R. A. (2002). Cruise ship blues: The underside of the cruise ship industry. New Society Publishers.

Mancini, M. (2003). Cruising: A guide to the cruise line industry. Delmar Learning.

Santangelo, R. A. (1984). What's happening in the cruise industry. Journal of Travel Research, 23.

Stokes, P. (1997). The ship finance-Credit expansion and the boom-bust cycle. Lloyd's of London Press

Stopford, M. (1997). Maritime economics. Routledge London.

Ward, D. (2005). Ocean cruising and cruise ships. London, England.

Wild, P. (2007). Cruise industry statistical review. Haywards Heath: GP Wild International Limited. 